\title{
Who Can Benefit from Robots? Effects of Individual Differences in Robot-Assisted Language Learning
}

\author{
Junko Kanero \\ Department of Psychology \\ Koç University \\ Istanbul, Turkey \\ jkanero@ku.edu.tr
}

\author{
Idil Franko \\ Department of Psychology \\ Koç University \\ Istanbul, Turkey \\ ifranko15@ku.edu.tr
}

\author{
Cansu Oranç \\ Department of Psychology \\ Koç University \\ Istanbul, Turkey \\ coranc14@ku.edu.tr
}

\author{
Orhun Uluşahin \\ Department of Psychology \\ Koç University \\ Istanbul, Turkey \\ oulusahin14@ku.edu.tr
}

\author{
Sümeyye Koşkulu \\ Department of Psychology \\ Koç University \\ Istanbul, Turkey \\ skoskulu17@ku.edu.tr
}

\author{
Zeynep Adigüzel \\ Department of Psychology \\ Koç University \\ Istanbul, Turkey \\ zadiguzel13@ku.edu.tr
}

\author{
Aylin C. Küntay \\ Department of Psychology \\ Koç University \\ Istanbul, Turkey \\ akuntay@ku.edu.tr
}

\author{
Tilbe Göksun \\ Department of Psychology \\ Koç University \\ Istanbul, Turkey \\ tgoksun@ku.edu.tr
}

\begin{abstract}
It has been suggested that some individuals may benefit more from social robots than do others. Using second language (L2) as an example, the present study examined how individual differences in attitudes toward robots and personality traits may be related to learning outcomes. Preliminary results with 24 Turkish-speaking adults suggest that negative attitudes toward robots, more specifically thoughts and anxiety about the negative social impact that robots may have on the society, predicted how well adults learned $\mathrm{L} 2$ words from a social robot. The possible implications of the findings as well as future directions are also discussed.
\end{abstract}

Keywords-human-robot interaction, second language, individual difference, robot-assisted language learning (RALL)

\section{INTRODUCTION}

Individual difference has been a hot topic in psychology for the past few decades [1]. Although traditional psychological research tends to focus on how humans generally think and behave, recent research has demonstrated the need for examining each individual because humans approach the same cognitive task in vastly different ways (e.g., [2]). Second language (L2) learning is no exception, and individual differences in various factors such as preference, attitudes, and personality must be considered. For example, some individuals may prefer to learn L2 through conversation with native speakers of the language whereas some others may prefer to sit alone at a desk and learn from books. Investigation of ways in which individual differences affect the process and outcomes of L2 learning is not only scientifically interesting, but also provides practical insights into how L2 learning experience can be improved by tailoring lessons for each individual learner. The current study uses robot-assisted L2 learning as an example to evaluate how individual differences predict the process and outcomes of learning, and discusses the

This research was supported in part by the EC H2020 L2TOR project (grant 688014). possibility of technology facilitating learning by providing personalized lessons.

The use of social robots in education is becoming more and more popular due to improvements in their quality and affordability. Although no previous research focused specifically on the effects of individual differences in robotassisted L2 learning, the idea has been suggested. For instance, examining word learning in fifth and sixth graders, Kanda, Hirano, Eaton, and Ishiguro (2004) found that children with some English proficiency or interest in English benefitted more from extra learning opportunities provided by social robots than did their peers with lower proficiency or interest [3]. Robots may be especially helpful for individuals with impaired social and communicative skills such as children with autism spectrum disorder (ASD). Social interactions with humans can sometimes be difficult or stressful for children with ASD because humans behave in very complex and unpredictable ways. Some researchers claim that robots can be good communication partners for those children as they can provide simpler and less stressful environments [4].

Some studies examined the relation between individual differences and how a person interacts with a robot. Ivaldi, Lefort, Peters, Chetouani, Provasi, and Zibetti (2017) examined the patterns of speech and eye gaze in 56 adults while they built an object with the humanoid robot iCub [5]. The study found that individuals who are high on extroversion tend to talk more with the robot, and individuals with a negative attitude towards robots tend to look less at the robot's face and more at the robot's hands. Tapus, Ţăpuş, and Matarić (2008) found that participants who were high on introversion interacted more with an introverted robot than an extroverted robot whereas participants who were high on extroversion interacted more with an extraverted robot than an introverted robot [6]. Takayama and Pantofaru (2009) found that having 
the personality trait of agreeableness decreases personal spaces when individuals approach robots, while having the personality trait of neuroticism and negative attitudes toward robots increase personal spaces when robots approach people [7]. These studies demonstrated that individual differences in negative attitudes toward robots and personality characteristics may predict how humans behave when they interact with a robot. However, the results are far from consistent, and more importantly, no study has examined whether individuals with different attitudes towards robots and with different personality traits learn to different levels from social robots.. Observing differences in human behaviors has scientific impact, but perhaps more important for human-robot interaction (HRI) research in individual differences is to move a step further and evaluate whether individuals with certain traits benefit more from robot companions than others. Robotassisted L2 learning is a perfect example to explore the issue as the learning outcomes such as test scores can be directly used to evaluate how effective and beneficial the robot companion is.

To examine ways in which individual differences affect how well humans learn from or with social robots, the present study examines language learning. This article focuses on part of a larger study and reports learning outcomes of an L2 lesson and its relationship with attitudes toward robots and personality traits. We chose attitudes toward robots as a possible predictor because of the previous findings (e.g., $[5,7]$ ), and because to assess the unique nature of robotassisted L2 lessons, it is critical to specifically examine individuals' attitudes toward robots. By assessing both negative attitudes toward robots and general personality traits such as openness to experience and extroversion, we are able to understand whether the observed relations between individual differences and learning outcomes are likely to be specific to robot-assisted L2 lessons as opposed to L2 lessons in general. For example, open-minded individuals may be more likely to learn from the robot because they are willing to interact with an unfamiliar agent and welcome the use of new technology or methods. Another possibility is that extraverted individuals benefit from any language lessons, whether with another person or a robot, because they enjoy communicating with another agent. In this study, we specifically tested the possibility that the learning outcomes of robot-assisted L2 lessons can be explained by the person's attitude towards robots. In other words, we tested the hypothesis that individuals who have positive attitudes toward robots are more likely to learn language from the lesson provided by a robot. We also tested the hypothesis that the relation is specific to attitudes towards robots and thus general personality traits such as openness to experience and extraversion do not predict the learning outcomes in robot-assisted L2 lessons.

\section{PARTICIPANTS}

Twenty-four Turkish speakers (Age range $=18.41-24.73$ years; $M_{\text {age }}=20.18$ years; $S D=1.56 ; 16$ females $)$ participated in the study. All participants were undergraduate and graduate students at Koç University in Istanbul, Turkey, who received course credits or monetary compensation for their participation. Participants had no known vision or hearing impairments. They were given the options of receiving monetary compensation or course credits for their participation.

\section{STIMULi}

\section{A. Pre-Lesson Test and Questionnaire}

Prior to the one-on-one English lesson with the NAO robot, participants completed one English test on paper and one survey on a desktop computer.

English Test. Oxford Quick Placement Test [8] was used to assess the English skills of participants. There were 60 multiple-choice questions in total.

Individual Difference Questionnaire. Total of 157 questions were prepared and all were put on one Qualtrics program to be completed on a desktop computer in the lab. This article specifically reports data from the following two sections concerning attitudes towards robots and personality traits.

- Attitudes toward robots. Negative Attitudes toward Robots Scale (NARS) was used to assess how participants feel about robots [9]. The NARS consists of 14 questions that can be divided into three subscales: negative attitude toward interacting with robots (S1, Questions 4, 7, 8, 9, 10, and 12), negative attitude toward social influence of robots (S2; Questions 1, 2, 11, 13, and 14), and negative attitude toward emotions involved in interaction with robots (S3; Questions 3, 5, and 6). Table I shows the Turkish version of the NARS that was developed by the first and second authors based on both the Japanese version [10] and the English version [9]. Participants rated how well each statement represents their negative attitudes toward robots on a scale of 1-5.

- Personality traits. Personality traits were measured based on the five-factor model of personality or "Big Five" - openness to experience, conscientiousness, extraversion, agreeableness, and neuroticism. We adapted the Turkish version of the Big Five survey used by Demir and Kumkale (2013) [11]. There were 45 questions in the survey that can be divided into five subscales: openness to experience (Questions 1-9), neuroticism (Questions 10-18), extraversion (Questions 19-27), conscientiousness (Questions 2836), and agreeableness (Questions 37-45). Participants 
TABLE I. THE TURKISH VERSION OF THE NEGATIVE ATTITUDES TOWARD ROBOTS SCALE (NARS; NOMURA, KANDA, \& SUZUKI, 2006) USED IN THE PRESENT STUDY.

\begin{tabular}{|c|c|}
\hline 1 & $\begin{array}{l}\text { Eğer robotların kendi duygulart olursa kaygllı hissederim. } \\
\text { (I will feel anxious if robots have their own emotions.) }\end{array}$ \\
\hline 2 & $\begin{array}{l}\text { Robotların insanlara daha çok benzemesinin insanoğlu açısından } \\
\text { olumsuz bir sonucu olacağını düşünüyorum. } \\
\text { (I surmise that there will be negative consequences for humans } \\
\text { when robots become more similar to humans.) }\end{array}$ \\
\hline 3 & $\begin{array}{l}\text { Robotlarla etkilessime girersem kendimi rahat hissederim. } \\
\text { (I will feel comfortable if I interact with robots.) }\end{array}$ \\
\hline 4 & $\begin{array}{l}\text { Robotların kullanildığı bir iş yerinde çalıştığımı hayal ettiğimde } \\
\text { kaygıll hissederim. } \\
\text { (I feel anxiety when I imagine that I may be employed or } \\
\text { assigned to a workplace where robots are used.) }\end{array}$ \\
\hline 5 & $\begin{array}{l}\text { Eger robotların kendi duygulart olursa kendimi onlara yakn } \\
\text { hissederim. } \\
\text { (I will feel close to robots if they have their own emotions.) }\end{array}$ \\
\hline 6 & $\begin{array}{l}\text { Robotların duygusal davrandıklarını gördüğ̈̈mde kendimi daha } \\
\text { rahat hissederim. } \\
\text { (I feel more comfortable when I see robots behaving affectively.) }\end{array}$ \\
\hline 7 & $\begin{array}{l}\text { Robotlar hakkında bir şey duyduğumda bile kendimi çaresiz } \\
\text { hissediyorum. } \\
\text { (I feel helpless even by hearing something about robots.) }\end{array}$ \\
\hline 8 & $\begin{array}{l}\text { Başkalarının önünde robot kullanacak olursam kendimi } \\
\text { utandırabilirim. } \\
\text { (I am likely to be embarrassed when I use robots in public.) }\end{array}$ \\
\hline 9 & $\begin{array}{l}\text { "Yapay zekanin verdiği kararlar" veya "robotlartn verdiği } \\
\text { kararlar" gibi ifadeler beni rahatsı ediyor. } \\
\text { (The words "artificial intelligence" or "decision by robots" make } \\
\text { me feel unpleasant.) }\end{array}$ \\
\hline 10 & $\begin{array}{l}\text { Sadece robotların önünde durmak bile bende gerginlik yaratır. } \\
\text { (Even standing in front of robots will strain me.) }\end{array}$ \\
\hline 11 & $\begin{array}{l}\text { Robotlara aşırı bağlı olmak gelecekte olumsuzluğa sebep } \\
\text { olabilir. } \\
\text { (I surmise that becoming extremely dependent on robots will } \\
\text { have negative consequences for humans in the future.) }\end{array}$ \\
\hline 12 & $\begin{array}{l}\text { Robotlarla etkileşime girersem kendimi tedirgin hissederim. } \\
\text { (I will feel nervous if I interact with robots.) }\end{array}$ \\
\hline 13 & $\begin{array}{l}\text { Robotların çocukların zihnini olumsuz yönde etkileyeceklerinden } \\
\text { korkuyorum. } \\
\text { (I am afraid that robots may negatively influence children's } \\
\text { minds.) }\end{array}$ \\
\hline 14 & $\begin{array}{l}\text { Gelecekteki toplumlara robotların hükmedeceği kanısindayım. } \\
\text { (I surmise that robots may dominate future societies.) }\end{array}$ \\
\hline
\end{tabular}
Note. English translations of the questions are in parentheses.

rated how well each of the statements represent their personality on a scale of 1-5.

\section{B. English Lesson with the NAO Robot}

Participants were taught eight English words - upholstery, barb, angler, caster, dromedary, cairn, derrick, and cupola. The words were selected from the last 40 items of the Peabody Picture Vocabulary Test, Fourth Edition (PPVT-4), which are supposed to be advanced for native English speakers [12]. The eight words were carefully selected so that (1) the Turkish equivalents of the words were not phonetically similar to them and (2) pronouncing the words should not be too difficult for Turkish speakers. With regard to the voice of the robot, instead
TABLE II. THE TARGET WORDS AND THEIR DEFINTIONS USED IN THE STUDY

\begin{tabular}{|l|l|}
\hline Target word & \multicolumn{1}{c|}{ Definition } \\
\hline upholstery & $\begin{array}{l}\text { Bu kelime döşemelik kumaş anlamina gelir } \\
\text { (This word means fabric that used to make a soft } \\
\text { covering) }\end{array}$ \\
\hline barb & $\begin{array}{l}\text { Bu kelime çengel ya da kanca anlamına gelir } \\
\text { (This word means the tip of an arrow or fishhook) }\end{array}$ \\
\hline angler & $\begin{array}{l}\text { Bu kelime olta ile balık tutan kimse anlamina gelir } \\
\text { (This word means a person who fishes with hook and } \\
\text { line) }\end{array}$ \\
\hline caster & $\begin{array}{l}\text { Bu kelime bir şeye takılan kü̧ük tekerlek anlamına } \\
\text { gelir } \\
\text { (This word means a little wheel attached to } \\
\text { something) }\end{array}$ \\
\hline dromedary & $\begin{array}{l}\text { Bu kelime tek hörgüçlü deve anlamina gelir } \\
\text { (This word means a one-humped camel) }\end{array}$ \\
\hline cairn & $\begin{array}{l}\text { Bu kelime taş ylğını anlamına gelir } \\
\text { (This word means a mound of stones) }\end{array}$ \\
\hline derrick & $\begin{array}{l}\text { Bu kelime petrol kuyusu üzerindeki kule anlamına } \\
\text { gelir } \\
\text { (This word means a tower over an oil well) }\end{array}$ \\
\hline cupola & $\begin{array}{l}\text { Bu kelime bir çatı üstüne inşa edilen küçük kubbe } \\
\text { benzeri yapı anlamına gelir } \\
\text { (This word means a rounded vault-like structure built } \\
\text { on top of a roof) }\end{array}$ \\
\hline
\end{tabular}

of using the default Turkish text-to-speech (TTS) library in NAO, we used the female voice available on Amazon Polly ("Filiz" for Turkish and "Salli" for American English). All speech was pre-recorded as WAV sound files.

\section{Post-Lesson Tests}

Two post-lesson tests, the productive vocabulary test (hereafter the productive test) and receptive vocabulary test (hereafter the receptive test), were administered immediately after the lesson and one week later. The definitions of the target words used in the productive test were the same as the definitions used in the lesson. In the receptive test, the pictures from the PPVT that correspond to the target words were used (see Procedure for the detail of the productive and receptive tests).

\section{DESIGN}

Participants were invited to the lab twice. The first visit was for the pre-lesson tests and survey (English Test and Individual Difference Questionnaire), the robot-assisted English lesson, and the immediate post-lesson tests (productive and receptive). The second visit was for the delayed postlesson tests (productive and receptive) and the post-lesson questionnaire. The robot was controlled through a Wizard-of$\mathrm{Oz}$ interface. We set one microphone behind the participant and four cameras at the corners of the ceiling, with which the "wizard" in another room monitored the participant in another room. 


\section{PROCEDURE}

On the first visit, the participant was first asked to take the English test. Participants were given 30 minutes to complete the test although they were allowed to finish it earlier and move on to the next task. Then, participants filled out the Individual Difference Questionnaire on a desktop computer. Participants were allowed to take as much time as they needed, and it took approximately 30 minutes to complete the entire questionnaire.

After completing the English Test and the questionnaire, the participant was instructed to go into a living room-like room by herself and to sit in front of the robot. The lesson began when the NAO robot recognized the participant saying "Merhaba (Hello)" (Fig. 1). The robot first briefly explained the structure of lesson, and then introduced the word one by one. Each target word was taught in four steps:

1. The robot introduced the target English word and asked the participant whether she already knew the word (Note that none of the participants knew any of the target words).

2. The robot introduced the definition of the target word (see Table II).

3. The robot asked the participant to utter the target word following the robot, for three times.

4. The robot again defined the word and asked the participant to repeat the definition.

After learning every two target words, the participant was also given a mini quiz in which the robot provided the definitions of the target words and asked the participant for the corresponding word. The lesson lasted for about 20 minutes.

At the end of the lesson, the robot asked the participant to leave the room and find the experimenter who was waiting in another room. The experimenter administered the immediate productive and receptive tests. In the productive test, the experimenter one by one provided the definitions of the learned English words as they were defined in the lessons, and the participant was asked to say the corresponding English word. In the receptive test, the participant heard the learned English word and was asked to point to a picture that matches with the word. Participants also completed a short post-lesson questionnaire that assessed how participants felt about NAO and robots in general after finishing the lesson.

All participants were re-invited to the lab one week later (Due to schedule conflicts, the second visit took place six days after the lesson for three participants and eight days after the lesson for one participant. Due to technical issues, another participant was invited to the lab three times- once for the prelesson test and questionnaire, once for the lesson, and once for the post-lesson tests and questionnaire but the delay between the lesson and the post-tests was seven days). On the second

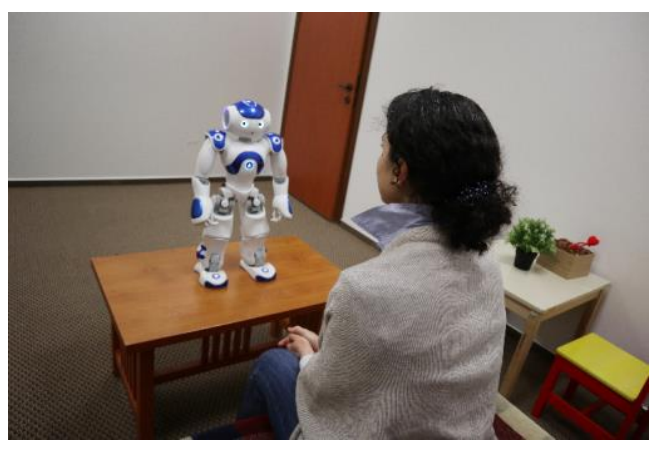

Fig. 1. The participant was instructed to go into a living room-like room by herself and to sit in front of the robot. The lesson began when the NAO robot recognized the participant saying "Merhaba (Hello)."

visit, participants again completed the productive and receptive tests. They also completed the short post-lesson questionnaire.

\section{RESULTS}

We examined whether individual differences in attitudes toward robots and personality traits predict the learning outcomes. The learning outcomes were measured in four postlesson tests: immediate productive test, immediate receptive test, delayed productive test, and delayed receptive test. Table III shows the descriptive statistics of all analyzed variables.

First, we examined whether the scores from each of the four post-lesson tests were correlated with the ratings from each of the three subscales of NARS (S1, S2, and S3) and overall scores or the ratings from each of the five subscales (openness to experience, conscientiousness, extraversion, agreeableness, and neuroticism). As shown in Table IV, several correlations were found between the test scores and the NARS scores. Namely, the overall NARS scores were correlated with the immediate receptive test, delayed productive test, and delayed receptive test. The scores for the second subscale S2 (i.e., negative attitude toward social influence of robots) were correlated with the scores from all four tests. Among the five personality traits, openness to experience was the only one with any significant correlation, and it was only with the delayed receptive test.

Second, we built regression models to evaluate interaction among different predictors. Prior to building a regression model, correlations among possible independent variables were calculated (Table V). Significant correlations were found between (1) S1 and S2, (2) S3 and openness to experience, (3) openness to experience and extraversion, and (4) extraversion and agreeableness. To avoid the issue of multicollinearity, S1 and S3 of the NARS were excluded from the analysis. With regard to the personality traits separate models were build. For each of the four tests, three regression models were built: Model 1 included as the second scale (S2) of the NARS as a sole predictor; Model 2 included S2 as well as openness to 
TABLE III. DESCRIPTIVE STATISTICS OF THE TEST SCORES AND INDIVIDUL DIFFERENCE MEASURES

\begin{tabular}{lrrrrr}
\hline & Mean & Median & SD & Min & Max \\
\hline Post-Lesson Tests & & & & & \\
Immediate Productive & 2.92 & 3.00 & 1.82 & 0 & 7 \\
Immediate Receptive & 5.13 & 5.00 & 2.03 & 1 & 8 \\
Delayed Productive & 1.46 & 1.00 & 1.59 & 0 & 5 \\
Delayed Receptive & 5.17 & 5.00 & 1.63 & 3 & 8 \\
NARS & & & & & \\
S1 & 11.83 & 12.00 & 4.77 & 6 & 27 \\
S2 & 14.92 & 15.50 & 4.42 & 5 & 23 \\
S3 & 7.92 & 7.50 & 2.81 & 3 & 14 \\
Personality & & & & & \\
Openess & 35.79 & 37.00 & 5.56 & 22 & 44 \\
Nauroticism & 33.04 & 34.00 & 6.50 & 19 & 46 \\
Extraversion & 32.33 & 31.50 & 5.78 & 24 & 45 \\
Conscientiousness & 24.71 & 24.50 & 4.81 & 16 & 34 \\
Agreeableness & 33.71 & 35.00 & 4.78 & 23 & 45 \\
\hline
\end{tabular}

TABLE IV. CORRELATIONS BETWEEN THE TEST SCORES AND INDIVIDUAL DIFFERENCE MEASURES

\begin{tabular}{llcccc}
\hline \multirow{2}{*}{ NARS } & & $\begin{array}{c}\text { Immediate } \\
\text { Productive }\end{array}$ & $\begin{array}{c}\text { Immediate } \\
\text { Receptive }\end{array}$ & $\begin{array}{c}\text { Delayed } \\
\text { Productive }\end{array}$ & $\begin{array}{c}\text { Delayed } \\
\text { Receptive }\end{array}$ \\
\hline \multirow{5}{*}{ Personality } & All & -.35 & $-.45^{*}$ & $-.63^{*}$ & $-.51^{*}$ \\
& $\mathrm{~S} 1$ & -.26 & -.25 & -.26 & -.30 \\
& $\mathrm{~S} 2$ & $-.49^{*}$ & $-.53^{*}$ & $-.49^{*}$ & $-.53^{*}$ \\
& $\mathrm{~S} 3$ & .05 & -.27 & .05 & -.38 \\
& $\mathrm{O}^{\mathrm{a}}$ & .10 & -.31 & .10 & $-.44^{*}$ \\
& $\mathrm{~N}^{\mathrm{b}}$ & .13 & -.07 & .13 & -.15 \\
& $\mathrm{E}^{\mathrm{c}}$ & .24 & -.19 & .24 & -.21 \\
& $\mathrm{C}^{\mathrm{d}}$ & .14 & -.27 & .14 & -.29 \\
& $\mathrm{~A}^{\mathrm{e}}$ & -.18 & .05 & -.18 & .03 \\
\hline
\end{tabular}

${ }^{\mathrm{a}} \mathrm{O}=$ Openness to experience; ${ }^{\mathrm{b}} \mathrm{N}=$ Neuroticism; ${ }^{\mathrm{c}} \mathrm{E}=$ Extraversion; ${ }^{\mathrm{d}} \mathrm{C}=$ Conscientiousness; ${ }^{\mathrm{e}} \mathrm{A}=$ Agreeableness ${ }^{*} p<.05$

TABLE V. CORRELATIONS AMONG THE INDEPENDENT VARIABLES

\begin{tabular}{|c|c|c|c|c|c|c|c|c|}
\hline & $\mathrm{S} 1$ & $\mathrm{~S} 2$ & $\mathrm{~S} 3$ & $\mathrm{O}$ & $\mathrm{N}$ & $\mathrm{E}$ & $\mathrm{C}$ & A \\
\hline S1 & & $.65^{*}$ & .27 & .06 & -.18 & -.02 & .17 & -.05 \\
\hline $\mathrm{S} 2$ & & & .25 & .11 & -.15 & .15 & .06 & -.14 \\
\hline S3 & & & & $.46^{*}$ & -.25 & .40 & .08 & .00 \\
\hline $\mathrm{O}^{\mathrm{a}}$ & & & & & -.23 & $.49^{*}$ & .08 & -.04 \\
\hline $\mathrm{N}^{\mathrm{b}}$ & & & & & & -.10 & .09 & -.07 \\
\hline$E^{c}$ & & & & & & & .00 & $-.51^{*}$ \\
\hline$C^{d}$ & & & & & & & & .07 \\
\hline $\mathrm{A}^{\mathrm{e}}$ & & & & & & & & \\
\hline
\end{tabular}

TABLE I. TABLE VI. REGRESSION MODELS FOR IMMEDIATE PRODUCTIVE TEST

\begin{tabular}{lcccc}
\hline & $B$ & $S E$ & $\beta$ & $t$ \\
\hline $\begin{array}{l}\text { Model 1 }{ }^{\mathrm{a}} \\
\text { NARS (S2) }\end{array}$ & -.24 & .08 & -.53 & $-2.95^{*}$ \\
$\begin{array}{l}\text { Model 2 } \\
\text { NARS (S2) }\end{array}$ & -.24 & .08 & -.52 & $-2.86^{*}$ \\
Openness & -.10 & .07 & -.28 & -1.54 \\
Neuroticism & -.06 & .06 & -.20 & -1.06 \\
Conscientiousness & -.08 & .08 & -.20 & -1.10 \\
Agreeableness & -.01 & .08 & -.03 & -.19 \\
Model 3 & & & & \\
NARS (S2) & -.22 & .08 & -.54 & $-2.92^{*}$ \\
Neuroticism & .02 & .05 & .07 & .37 \\
Extraversion & .10 & .06 & .33 & 1.79 \\
Conscientiousness & .06 & .07 & .16 & .88 \\
\hline \multicolumn{2}{c}{$N=24 ;{ }^{\mathrm{a}}$ Overall $R^{2}=.28 ;{ }^{\mathrm{b}}$ Overall $R^{2}=.43 ;{ }^{\mathrm{c}}$ Overall $R^{2}=.38 ;{ }^{*} p<.05}$.
\end{tabular}

TABLE II. TABLE VII. REGRESSION MODELS FOR THE IMMEDIATE RECEPTIVE TEST

\begin{tabular}{lcccc}
\hline & $B$ & $S E$ & $\beta$ & $t$ \\
\hline Model 1 $^{\mathrm{a}}$ & & & & \\
$\quad$ NARS (S2) & -.25 & .05 & -.71 & $-4.68^{*}$ \\
Model 2 ${ }^{\mathrm{b}}$ & & & & \\
$\quad$ NARS (S2) & -.25 & .06 & -.70 & $-4.23^{*}$ \\
Openness & -.04 & .05 & -.14 & -.81 \\
Neuroticism & .00 & .04 & .02 & .11 \\
Conscientiousness & .00 & .05 & .01 & .04 \\
$\quad$ Agreeableness & -.04 & .05 & -.11 & -.67 \\
Model 3 & & & & \\
NARS (S2) & -.24 & .09 & -.52 & $-2.81^{*}$ \\
Neuroticism & -.04 & .06 & -.14 & -.75 \\
Extraversion & -.04 & .06 & -.13 & -.68 \\
Conscientiousness & -.10 & .08 & -.23 & -1.26 \\
\hline \multicolumn{2}{c}{$N=24 ;{ }^{\mathrm{a}}$ Overall $R^{2}=.28 ;{ }^{\mathrm{b}}$ Overall $R^{2}=.43 ;{ }^{\mathrm{c}}$ Overall $R^{2}=.37{ }^{*} p<.05}$.
\end{tabular}

experience, neuroticism, conscientiousness, and agreeableness as predictors. Model 3 was built to test extraversion which could not be tested in Model 2. In addition to S2 and extraversion, neuroticism and conscientiousness were included in Model 3 as they were not correlated with extraversion.

Table VI shows the details of the regression models. According to the $R^{2}$ value, when S2 of the NARS was the sole predictor, the model explained $28 \%$ of the variance in the immediate productive test (Model 1). When openness to experience, neuroticism, conscientiousness, and agreeableness were included, the model explained $43 \%$ of the variance in the test scores (Model 2). When neuroticism, extraversion, and conscientiousness were included, the model explained $38 \%$ of the variance in the immediate productive test (Model 3). However, in all three models, S2 was the only significant predictor. The pattern was largely the same for the immediate receptive test (Table VII). In all three models, S2 was again the only significant predictor. The percentage of the variance 
in the immediate receptive test explained by Models 1, 2, and 3 was $28 \%, 43 \%$, and $37 \%$, respectively.

S2 was a significant predictor for all six models built for the delayed tests. $R^{2}$ were $.50, .53$, and .50 for Models $1-3$ of the delayed production test, and .30, .52, and .38 for Models 13 of the delayed receptive test. Thus, S2 explained a larger variance in the delayed tests than in the immediate tests. In addition, openness to experience was a significant predictor in Model 2 of the delayed receptive test $(B=-.17 ; S E=.06, \beta=$ $.47 ; t=-2.79$ ), suggesting that individuals with the personality trait of openness to experience tend to score low in the test.

\section{DISCUSSION}

The present study examined whether and how individual differences in attitude towards robots as well as personality traits affect learning outcomes of robot-assisted L2 lessons. We hypothesized that (1) individuals who have positive attitudes toward robots are more likely to learn L2 words from the lesson provided by a robot, and (2) the relation would be specific to attitudes towards robots and thus general personality traits such as openness to experience do not predict learning outcomes. Our preliminary data suggest that the responses to $\mathrm{S} 2$ of the NARS was negatively correlated with the scores of all post-lesson tests. When S2 was put into regression models with personality trait factors, S2 remained as the only significant predictor except that openness to experience was also a significant predictor in the model for the delayed receptive test. As negative attitude towards robots but not general personality traits predicted the learning outcomes, it is safe to suggest that how people learn L2 in robot-assisted lessons is affected by their attitudes toward robots.

Importantly, S2 is a scale for negative attitude toward social influence of robots, and is composed of four statements including " 1 . I feel anxiety if robots really have their own emotions," "2. I surmise that something negative for humans happen when robots become more similar to humans," "11. I surmise that extreme dependence on robots may cause something negative for humans in future," "13. I am afraid that robots may negatively influence children's mind," and "14. I surmise that future societies may be dominated by robots." Therefore, our results suggest that those who are afraid of robots becoming like humans and influencing human life are less likely to learn language from robots. Whereas other two scales concern participants' expectations about personal interaction with robots they themselves may experience, S2 concerns abstract fear and anxiety people have towards robots.

Although this study demonstrated the relation between learning outcomes and general and somewhat abstract negative attitudes toward robots, the mechanism underlies this relation is still unknown. We speculate that, an individual with negative attitudes toward robots is unlikely to pay attention to the robot tutor and learn well. The current data do not allow us to evaluate this possibility, and more experiments are needed to understand the relation. It is also critical to conduct the current study with human-led lessons in order to assess whether observed relations are truly specific to robot tutors. Our team is working on experiments to assess these issues in addition to recruiting more participants to the current study.

\section{CONCLUSION}

Researchers and educators have long been aware of the importance of recognizing individual differences. However, the topic has not received enough attention perhaps because it is unrealistic for teachers to provide personalized lessons for each individual student. Research on human-robot interaction can shed a light to the situation. By attitudes toward robots and personality traits, our study provides novel and unique insights on how robots can be used in humans learn a new language.

\section{REFERENCES}

[1] Mayer, R. E. (2003). What causes individual differences in cognitive performance? In R. J. Sternberg \& E. L. Grigorenko (Eds.), The psychology of abilities, competencies, and expertise (pp. 263-273). New York, NY, USA: Cambridge University Press.

[2] van Someren, M.W., Barnard, R., \& Sandberg. J. (1994). The think aloud method: a practical guide to modelling cognitive processes, London, UK: Academic Press.

[3] Kanda, T., Hirano, T., Eaton, D., \& Ishiguro, H. (2004). Interactive robots as social partners and peer tutors for children: A field trial. Human-computer interaction, 19(1), 61-84.

[4] Robins, B., Dautenhahn, K., \& Boekhorst, R. T. (2005). Universal Access in the Information Society, 4(2), 105-120.

[5] Ivaldi, S., Lefort, S., Peters, J., Chetouani, M., Provasi, J., \& Zibetti, E. (2017). Towards engagement models that consider individual factors in HRI: on the relation of extroversion and negative attitude towards robots to gaze and speech during a human-robot assembly task. International Journal of Social Robotics, 9(1), 63-86.

[6] Tapus, A., Tăpuş, C., \& Matarić, M. J. (2008). User-Robot Personality Matching and Robot Behavior Adaptation for Post-Stroke Rehabilitation Therapy, Intelligent Service Robotics Journal, Special Issue on Multidisciplinary Collaboration for Socially Assistive Robotics, 1(2), 169-183.

[7] Takayama, L., \& Pantofaru, C. (2009). Influences on proxemic behaviors in human-robot interaction. Proceedings of the 2009 IEEE/RSJ International Conference on Intelligent Robots and Systems (IROS),

[8] G. Syndicate, U. C. L. E. (2001). Quick Placement Test. Oxford, UK: Oxford University Press.

[9] Nomura, T., Kanda, T., \& Suzuki, T. (2006). Experimental Investigation into Influence of Negative Attitudes toward Robots on Human-Robot Interaction. AI \& Society, 20(2), 138-150.

[10] Nomura, T., Kanda, T., Suzuki, T. Yamada, S., \& Kato, K. (2010). Human Attitudes, Anxiety, and Behaviors in Human-Robot Interation (HRI). Proceedings of the 26th Fuzzy System Symposum, 554-559.

[11] Demir, B., \& Kumkale, G. T. (2013). Individual differences in willingness to become an organ donor: A decision tree approach to reasoned action. Personality and Individual Differences, 55 (1), 63-69.

[12] Dunn, L. M., \& Dunn, D. M. (2007). Peabody Picture Vocabulary Test - Fourth edition (PPVT). Minneapolis, MN: NCS Pearson. 